\title{
GAMBARAN AKTIVITAS SEDENTARI DAN TINGKAT KECUKUPAN GIZI PADA REMAJA GIZI LEBIH DAN GIZI NORMAL
}

\author{
Sedentary Activity and Nutrient Adequacy Level among Overweight and Normal Adolescent
}

\author{
Sofia Rahma Pramudita ${ }^{1}$, Siti Rahayu Nadhiroh ${ }^{2}$ \\ ${ }^{1}$ Program Studi S1 Kesehatan Masyarakat, Fakultas Kesehatan Masyarakat, Universitas Airlangga, Surabaya \\ ${ }^{2}$ Departemen Gizi Kesehatan, Fakultas Kesehatan Masyarakat, Universitas Airlangga, Surabaya \\ Email: sofiarahma1906@gmail.com
}

\begin{abstract}
ABSTRAK
Aktivitas sedentari adalah aktivitas yang membutuhkan pengeluaran energi yang sangat rendah, seperti duduk atau berbaring sambil menonton televisi, bermain game elektronik, dan membaca yang dapat menimbulkan efek negatif pada kesehatan. Salah satu dampak negatifnya yaitu berisiko mengalami obesitas. Tujuan dari penelitian ini adalah untuk menggambarkan tingkat kecukupan dan aktivitas sedentari remaja berstatus gizi lebih dan berstatus gizi normal. Penelitian ini merupakan penelitian deskriptif dengan sampel sebanyak 70 siswa-siswi SMPN 3 Gresik yang terbagi menjadi dua kelompok, masing-masing pada tiap kelompok status gizi lebih dan normal terdiri dari 35 anak. Data asupan gizi, aktivitas sedentari, dan pengukuran tinggi badan dan berat badan diperoleh dari kuesioner dan wawancara langsung pada responden. Berdasarkan penelitian didapatkan hasil bahwa pada sebagian besar remaja gizi lebih memiliki tingkat kecukupan energi dan karbohidrat yang lebih dari 77\% AKG dibandingkan dengan remaja gizi normal. Tingkat kecukupan protein dan lemak antara remaja gizi lebih dan normal cenderung memiliki tingkat kecukupan yang sama. Remaja gizi lebih memiliki tingkat aktivitas sedentari tinggi yang lebih besar daripada gizi normal. Sebagian besar remaja berstatus gizi lebih memiliki tingkat kecukupan energi, karbohidrat, dan aktivitas sedentari lebih tinggi daripada gizi normal. Mengurangi konsumsi makanan yang manis, berlemak, dan menambah konsumsi buah dan sayur, serta meningkatkan aktivitas fisik dengan cara olahraga rutin perlu dilakukan oleh responden.
\end{abstract}

Kata kunci: aktivitas sedentari, remaja, status gizi lebih, tingkat kecukupan gizi

\begin{abstract}
Sedentary activity is an activity that requires very low energy expenditure, such as sitting or lying down while watching television, playing electronic games, and reading that can cause negative effects on health. One of the negative impact is increasing risk for obesity. The purpose of this study was to describe the nutrition adequacy level and sedentary activity among overweight and normal adolescent. This research was descriptive study with cross-sectional design. The sample was 70 students of SMPN 3 Gresik which divided into two groups based on their nutritional status, overweight or normal with 35 samples in each group. Data of nutrient intake, sedentary activity, and measurements of height and weight obtained from questionnaires and direct interview with respondents. Research showed that majority of overweight adolescent, had an energy and carbohydrate adequacy levels more than 77\% of RDA compared to normal adolescent. Overweight and normal adolescents have a similar protein and fat adequacy level. Overweight adolescents had greater sedentary activity level the normal one. Majority of overweight adolescent have higher adequacy level of energy, carbohydrate, and sedentary activity than normal adolescent. Reducing consumption of sweet, fatty foods, increase consumption of fruits and vegetables, also increase regular physical activity need to be done by the respondent.
\end{abstract}

Keywords: sedentary activity, adolescents, overweight, nutrient adequacy level

\section{PENDAHULUAN}

Overweight dan obesitas berpengaruh terhadap usia harapan hidup seseorang (Duncan, et al., 2011). Overweight dan obesitas merupakan suatu kelainan yang ditandai dengan penimbunan lemak tubuh secara berlebih (WHO, 2010). Masalah overweight dan obesitas pada usia remaja 13-15 tahun di Indonesia sebesar 10,8\% yang terdiri dari 
$8,3 \%$ overweight dan $2,5 \%$ obesitas (Kemenkes RI, 2013). Seseorang yang sudah mengalami overweight dan obesitas sejak masa anak-anak mempunyai risiko yang lebih tinggi terkena penyakit-penyakit metabolik (Ekelund, et al., 2007). Overweight dan obesitas pada remaja usia 13-15 tahun di Jawa Timur masih cukup tinggi karena angka prevalensi overweight dan obesitas di Jawa Timur di atas prevalensi nasional yakni $12 \%$, sedangkan prevalensi overweight dan obesitas berdasarkan IMT/U di Kabupaten Gresik sebesar 18,7\% (Kemenkes RI, 2013).

Overweight dan obesitas merupakan penyakit multifaktorial yang disebabkan interaksi faktor internal dan eksternal. Faktor internal yang dapat mempengaruhi terjadinya overweight dan obesitas adalah genetik, kelainan endokrin, dll. Selain faktor internal, overweight dan obesitas juga dapat dipengaruhi oleh faktor eksternal. Faktor eksternal yang dapat mempengaruhi terjadinya obesitas adalah gaya hidup atau tingkah laku dan faktor lingkungan. Sebagian besar overweight dan obesitas disebabkan karena faktor eksternal sedangkan faktor internal hanya menyumbang $10 \%$ (Atkinson, et al., 2005). Salah satu faktor eksternal yaitu aktivitas fisik memiliki hubungan terhadap overweight dan obesitas dibanding dengan faktor eksternal lainnya. Aktivitas fisik menyumbangkan pengeluaran energi sebesar 20-50\%. Kurangnya aktivitas fisik menyebabkan terjadinya kelebihan energi yang pada akhirnya disimpan dalam bentuk jaringan lemak (Guow, et al., 2010). Overweight dan obesitas pada usia remaja awal berhubungan dengan kebiasaan tidak aktif yang mengarah pada kebiasaan gaya hidup sedentari (Ochoa, et al., 2007).

Gaya hidup sedentari adalah perilaku yang terjadi saat duduk atau berbaring yang membutuhkan pengeluaran energi yang sangat rendah, seperti duduk atau berbaring sambil menonton televisi, bermain game elektronik, membaca, dan lain sebagainya. Perkembangan teknologi yang serba instant dapat menyebabkan perubahan gaya hidup tradisional menjadi gaya hidup sedentari. Gaya hidup yang sedentari dapat menurunkan aktivitas fisik dan meningkatkan risiko untuk menjadi obesitas dan overweight (Arundhana, et al., 2013). Penelitian ini bertujuan untuk mendeskripsikan tingkat aktivitas sedentari dan konsumsi remaja gizi lebih dan gizi normal.

\section{METODE}

Penelitian ini merupakan penelitian observasional dengan desain case control yang bertujuan untuk mendeskripsikan tingkat aktivitas sedentary dan tingkat kecukupan zat gizi pada remaja gizi lebih dan gizi normal. Populasi penelitian ini adalah seluruh siswa-siswi SMPN 3 Gresik usia 13-15 tahun yang telah melakukan penimbangan berat badan. Sampel penelitian adalah remaja usia 13-15 tahun yang mengalami gizi lebih dan gizi normal.

Menurut perhitungan sampel minimal dengan rumus dua populasi berdasarkan proporsi, maka didapatkan jumlah sampel minimal tiap kelompok untuk remaja status gizi lebih dan normal adalah masing-masing 35 remaja sehingga total jumlah sampel yang diambil dalam penelitian sebesar 70 remaja. Teknik pengambilan sampel dilakukan secara acak dengan menggunakan metode simple random sampling.

Pengambilan data primer dilakukan dengan wawancara menggunakan kuesioner, formulir food recall, kuesioner ASAQ (Adolescent Sedentary Activity Questionnaire), serta pengukuran antropometri remaja untuk berat badan dan tinggi badan menggunakan timbangan digital dan microtoise. Pengumpulan data sekunder tentang data siswa-siswi dan status gizi diperoleh dari pihak SMPN 3 Gresik.

Data konsumsi remaja gizi lebih dan gizi normal yang diperoleh dari data primer akan dianalisis menggunakan software nutrisurvey, sedangkan data berat badan dan tinggi badan, dihitung Indeks Massa Tubuh menurut usia (IMT/U) dan diklasifikasikan dalam remaja gizi lebih atau remaja gizi normal. Kemudian, hasil dari nutrisurvey, akan dikategorikan berdasarkan AKG remaja menurut jenis kelamin dan usia jika $>77 \%$ mencukupi AKG dan $\leq 77 \%$ tidak mencukupi AKG.

Data aktivitas sedentari pada penelitian ini didapatkan dari hasil wawancara menggunakan kuesioner ASAQ, aktivitas sedentari alam penelitian ini dikategorikan menjadi aktivitas SSR 
(Small Screen Recreation), aktivitas sedentary education, aktivitas sedentary travel, aktivitas sedentary cultural, dan aktivitas sedentary social. Data disajikan dalam bentuk narasi dan tabel frekuensi.

\section{HASIL DAN PEMBAHASAN}

\section{Aktivitas Sedentari}

Berdasarkan Tabel 1, dapat diketahui bahwa sebagian besar remaja dengan status gizi lebih melakukan aktivitas sedentari tinggi $>8 \mathrm{jam} /$ hari sejumlah 31 orang $(88,6 \%)$ dan $\leq 8$ jam/hari sejumlah 4 orang $(11,4 \%)$. Remaja dengan gizi normal memiliki tingkat aktivitas sedentari tinggi $>8 \mathrm{jam} /$ hari hanya sebesar $2,9 \%$ dan aktivitas sedentari rendah $\leq 8 \mathrm{jam} / \mathrm{hari}$ sebesar 34 orang $(97,1 \%)$. Sebagian besar remaja dengan status gizi lebih memiliki tingkat aktivitas sedentari yang tinggi $>8$ jam/hari.

Hasil penelitian tersebut sesuai dengan penelitian Kudraningsih (2016) yang mengatakan overweight dan obesitas disebabkan menurunnya aktivitas fisik dan meningkatnya gaya hidup sedentari. Penelitian Lowry, et al., (2002), dan Gomez, et al., (2007) juga menyatakan bahwa menonton TV lebih dari dua jam per hari berisiko untuk mengalami obesitas dan overweight. Kegiatan SSR (Small Screen Recreation) mengharuskan seseorang untuk sedikit mengelurkan energi sehingga asupan energi yang masuk kedalam tubuh banyak yang disimpan ke dalam jaringan lemak. Penelitian yang dilakukan Kudraningsih (2016) menjelaskan bahwa remaja dan orang dewasa yang pergi ke sekolah dan bekerja dengan berjalan atau bersepeda tidak berisiko untuk menjadi overweight dan obesitas. Namun sebaliknya, jika remaja dan orang dewasa berpergian dengan kendaraan bermotor dapat mengakibatkan kelebihan berat badan. Berjalan baik untuk kesehatan karena dapat meningkatkan fungsi kardiovaskular. Berjalan dapat menjadi sarana untuk gaya hidup aktif yang dapat meningkatkan aktivitas fisik dan mengurangi risiko obesitas.

Selain itu, obesitas dan overweight pada remaja dapat disebabkan oleh beberapa faktor. Faktor-faktor yang dapat berkonstribusi terhadap terjadinya kelebihan berat badan adalah faktor lingkungan dan faktor genetik. Menurut Hadi, et al., (2004), faktor yang dapat memberikan konstribusi kelebihan berat badan dan obesitas pada remaja adalah menurunnya aktivitas fisik dan meningkatnya aktivitas sedentari.

\section{Tingkat Kecukupan Zat Gizi}

Berdasarkan hasil penelitian (Tabel 1) didapatkan tingkat kecukupan energi yang lebih dari $77 \%$ AKG pada remaja dengan status gizi lebih berjumlah 32 orang $(91,4 \%)$ dan yang tidak dapat mencukupi $(<77 \%$ AKG) sebesar 9,4\%. Berbeda dengan remaja gizi normal, tingkat kecukupan energi yang memenuhi $>77 \%$ AKG hanya 19 orang $(54,3 \%)$ dan yang tidak dapat mencukupi $\leq 77 \%$ AKG sebanyak 16 orang (45,7\%). Dari hasil penelitian tersebut, remaja gizi lebih memiliki kecenderungan lebih besar untuk mencukupi $>77 \%$ AKG daripada remaja gizi normal. Hal tersebut sesuai dengan penelitian Loliana dan Nadhiroh (2015) yang menemukan adanya perbedaan yang bermakna pada kecukupan energi dari kelompok remaja gizi lebih dan gizi normal. Asupan energi yang berlebihan dan tidak diimbangi dengan aktivitas fisik dapat menyebabkan kelebihan berat badan. Hal ini sesuai dengan pendapat Michael dan Melinda (2006) yang menyatakan bahwa kelebihan berat badan pada remaja disebabkan karena ketidakseimbangan antara energi yang masuk dan energi yang dibutuhkan. Kelebihan energi dalam tubuh akan disimpan dalam bentuk jaringan lemak dan menyebabkan kenaikan berat badan (Almatsier, 2009).

Berdasarkan Tabel 1, dapat diketahui bahwa sebagian besar tingkat kecukupan karbohidrat yang mencukupi $>77 \%$ AKG pada remaja dengan status gizi lebih sebesar 25 orang $(71,4 \%)$ sedangkan yang tidak mencukupi $\leq 77 \%$ AKG sebanyak 10 orang $(28,6 \%)$. Pada remaja dengan status gizi normal, tingkat kecukupan karbohidrat yang tergolong mencukupi $>77 \%$ AKG sebesar 10 orang $(28,6 \%)$ dan yang tidak mencukupi $\leq 77 \%$ AKG sebanyak 25 orang $(71,4 \%)$. Remaja dengan gizi lebih cenderung lebih banyak yang telah mencukupi $>77 \%$ AKG dibandingkan dengan remaja gizi normal. Tingginya asupan kalori salah satunya dapat berasal dari konsumsi makanan berdensitas energi tinggi. Menurut Smith (2006), 
makanan yang disukai remaja pada umumnya memiliki persentase kalori yang tinggi berasal dari karbohidrat, misalnya permen, soft drink, fast food, dan kue manis. Sebaliknya, apabila kebutuhan karbohidrat tidak tercukupi, maka protein akan diubah menjadi glukosa untuk dijadikan sebagai sumber energi (Almatsier, 2009).

Berdasarkan hasil penelitian (Tabel 1) didapatkan tingkat kecukupan protein remaja dengan status gizi lebih yang mencukupi $>77 \%$ AKG sebesar 31 orang $(88,6 \%$ ), dan yang tidak mencukupi $\leq 77 \%$ AKG sebanyak 4 orang $(11,4 \%)$. Remaja dengan status gizi normal memiliki tingkat kecukupan protein sebesar 27 orang $(77,1 \%)$ sedangkan yang tidak mencukupi $\leq 8$ orang $(22,9 \%)$. Hasil tersebut menunjukkan kecenderungan bahwa tingkat kecukupan protein antara remaja gizi lebih dan gizi normal cenderung sama. Sependapat dengan penelitian Sasmito (2015) bahwa tidak terdapat perbedaan yang bermakna antara kecukupan protein remaja gizi lebih dengan remaja gizi normal. Hal ini disebabkan karena obesitas dapat terjadi karena faktor genetik atau jarang melakukan aktivitas fisik.

Tingkat kecukupan lemak yang tergolong mencukupi $>77 \%$ pada remaja gizi lebih sebesar
29 orang $(82,9 \%)$ dan yang tidak mencukupi $\leq 7 \%$ AKG sebanyak 6 orang (17,1\%). Pada remaja gizi normal tingkat kecukupan lemak yang mencukupi $>77 \%$ AKG sebanyak 27 orang $(77,1 \%)$ yang tidak mencukupi $\leq 7 \%$ AKG sebanyak 8 orang $(22,9 \%)$. Pada tingkat kecukupan lemak antara remaja gizi lebih dan gizi normal memiliki tingkat kecukupan lemak yang cenderung sama. Hal tersebut sejalan dengan penelitian Amelia (2008) dan Fitriana (2011) yang menjelaskan bahwa tidak terdapat perbedaan tingkat kecukupan lemak dan protein pada remaja dengan gizi lebih dan gizi normal.

\section{KESIMPULAN DAN SARAN}

Dari hasil penelitian yang dilakukan terhadap remaja dengan status gizi lebih dan normal di SMPN 3 Gresik dapat ditarik kesimpulan bahwa terdapat kecenderungan remaja dengan gizi lebih memiliki tingkat kecukupan dan tingkat aktivitas sedentari yang lebih besar daripada remaja gizi normal di SMPN 3 Gresik.

Diperlukan upaya untuk mengoptimalkan kecukupan zat gizi dengan cara mengurangi konsumsi makanan yang manis, berminyak, dan mengandung soda, serta memperbanyak konsumsi

Tabel 1. Distribusi Silang Status Gizi Remaja berdasarkan Tingkat Kecukupan Zat Gizi dan Tingkat Aktivitas Sedentary Remaja

\begin{tabular}{|c|c|c|c|c|c|}
\hline \multirow{3}{*}{ Klasifikasi } & \multicolumn{4}{|c|}{ Status Gizi Remaja } & \multirow{3}{*}{$\begin{array}{c}\text { Total } \\
(\mathrm{N}=\mathbf{7 0})\end{array}$} \\
\hline & \multicolumn{2}{|c|}{$\begin{array}{l}\text { Gizi lebih } \\
(n=35)\end{array}$} & \multicolumn{2}{|c|}{$\begin{array}{c}\text { Gizi Normal } \\
(\mathrm{n}=\mathbf{3 5})\end{array}$} & \\
\hline & $\mathbf{n}$ & $\%$ & $\mathbf{n}$ & $\%$ & \\
\hline \multicolumn{6}{|l|}{ Tingkat Kecukupan Energi } \\
\hline$>77 \% \mathrm{AKG}$ & 32 & 91,4 & 19 & 54,3 & 51 \\
\hline$\leq 77 \% \mathrm{AKG}$ & 3 & 8,6 & 16 & 45,7 & 19 \\
\hline \multicolumn{6}{|c|}{ Tingkat Kecukupan Karbohidrat } \\
\hline$>77 \% \mathrm{AKG}$ & 25 & 71,4 & 10 & 28,6 & 35 \\
\hline$\leq 77 \% \mathrm{AKG}$ & 10 & 28,6 & 25 & 71,4 & 35 \\
\hline \multicolumn{6}{|c|}{ Tingkat Kecukupan Protein } \\
\hline$>77 \% \mathrm{AKG}$ & 31 & 88,6 & 27 & 77,1 & 58 \\
\hline$\leq 77 \% \mathrm{AKG}$ & 4 & 11,4 & 8 & 22,9 & 12 \\
\hline \multicolumn{6}{|l|}{ Tingkat Kecukupan Lemak } \\
\hline$>77 \% \mathrm{AKG}$ & 29 & 82,9 & 27 & 77,1 & 56 \\
\hline$\leq 77 \% \mathrm{AKG}$ & 6 & 17,1 & 8 & 22,9 & 14 \\
\hline \multicolumn{6}{|l|}{ Tingkat Aktivitas Sedentari } \\
\hline Rendah & 4 & 11,4 & 34 & 9,7 & 38 \\
\hline Tinggi & 31 & 88,6 & 1 & 2,9 & 32 \\
\hline
\end{tabular}


buah-buahan dan sayur-sayuran. Melakukan penimbangan berat badan dan pengukuran tinggi badan secara rutin pada siswa-siswi SMPN 3 Gresik agar dapat memantau pertumbuhan dan pertambahan berat badan. Diperlukan penambahan aktivitas fisik siswa-siswi dengan memberikan inovasi pada saat pelajaran berlangsung supaya siswa-siswi tetap aktif bergerak misalnya moving class, pembelajaran dengan game dan lain sebagainya. Siswa-siswi diharapkan dapat membiasakan diri dengan ketika berpergian pada jarak dekat tidak perlu menggunakan kendaraan bermotor.

\section{DAFTAR PUSTAKA}

Almatsier, S. (2009). Prinsip dasar ilmu gizi. Jakarta: Gramedia Pustaka Utama.

Amelia, F. (2008). Konsumsi pangan, pengetahuan gizi, aktivitas fisik dan status gizi pada remaja di Kota Sungai Penuh Kabupaten Kerinci Provinsi Jambi. (Skripsi tidak diterbitkan). Institut Pertanian Bogor, Bogor.

Arundhana, A.I., Thaha, R., \& Jafar, N. (2013). Aktivitas fisik dan asupan kalsium sebagai faktor risiko obesitas. Buletin Gizi Kita DIY, 12(2), 68-80.

Atkinson, K., Karlson, E.W., \& Curhan, G. (2005). Obesity, weight change, hypertension, diuretic use, and risk of gout in men: The health professionals follow-up study. Arch Intern Med, 165(7), 742-748. doi:10.1001/ archinte.165.7.742

Duncan, S., Duncan, E.K., Fernandes, R.A., Buonani, C., Bastos, K., Segatto, A., Codogno, J.S., Gomes, I.C., \& Freitas, I.F. (2011). Modifiable risk factors for overweight and obesity in children and adolescents from São Paulo, Brazil. Bio Med Central Public Health, 11, 585. Diakses dari https://bmcpublichealth. biomedcentral.com/articles/10.1186/14712458-11-585

Ekelund, U., Brage, S., Froberg, K., Harro, M., Anderssen, S.A., \& Sardinha, L.B. (2007). TV viewing and physical activity are independently associated with metabolic risk in children: The European Youth Heart study. PLoS Med, 3(12), 2449-2457. Diakses dari https://www.ncbi. nlm.nih.gov/pmc/articles/PMC1705825/pdf/ pmed.0030488.pdf
Fitriana, N. (2011). Kebiasaan sarapan, aktivitas fisik, dan status gizi mahasiswa mayor ilmu gizi dan mayor konservasi sumberdaya hutan dan ekowisata IPB. Diakses dari http://repository. ipb.ac.id/handle/123456789/51419.

Gomez, L.F., Parra, D.C., Lobelo, F., Samper, B., Moreno, J., Jacoby, E., \& Borda, C. (2007). Television viewing and its association with overweight in Colombian children: results from the 2005 National Nutrition Survey: a cross sectional study. Intern J Behav Nutr Phys Act, 4, 41. doi: 10.1186/1479-5868-4-41

Gouw, D., Klepp, K.I., Vignerova, J., Lien, N., Steenhuis, I.H., \& Wind, M. (2010). Associations between diet and (in) activity behaviours with overweight and obesity among 10-18-year-old Czech Republic adolescents. Public Health Nutr, 13(10A):17 1701-1707. doi: 10.1017/ S1368980010002259

Hadi, H., Huriyati, E., \& Julia, M. (2004). Aktivitas fisik pada remaja SLTP Kota Yogyakarta dan Kabupaten Bantul serta hubungannya dengan kejadian obesitas. The Indonesian J Clin Nutr, 1(2), 59-65.

Kemenkes RI. (2013). Laporan hasil riset kesehatan dasar 2013. Jakarta: Balitbangkes RI.

Kudraningsih, S.V., Toto, S., \& Lely, L. (2016). Physical activity and sedentary lifestyle towards teenagers' overweight/obesity status. Int J Community Med Public Health. 3(3), 630-635.

Loliana, N., \& Nadhirah, S.R. (2015). Asupan dan kecukupan gizi antara remaja obesitas dengan non obesitas. Media Gizi Indonesia, 10 (2),141145.

Lowry R, Wechsler H, Galuska D.A., Fulton, J.E., \& Kann, L. (2002). Television viewing and its associations with overweight, sedentary lifestyle, and insufficient consumption of fruits and vegetables among US high school students: differences by race, ethnicity, and gender. $J$ School Health, 72(10), 413-421.

Michael I.G., Melinda S. (2006). Handbook of padiatric obesity etiology, pathophsyiology and prevention. USA: Taylor \& Francis Group.

Ochoa, M., Moreno, A., Martinez, A., \& Marti, A. 2013. Predictor factors for childhood obesity in a spanish case control study. Nutrition Journal, 23,379-384. Diakses dari http://www.ncbi.nlm. nih.gov/pubmed/17408922 
Sasmito, P.D. (2015). Hubungan asupan zat gizi makro (karbohidrat, protein, lemak) dengan kejadian obesitas pada remaja umur 13- 15 tahun di propinsi DKI Jakarta (Analisis data sekunder Riskesdas 2010). Nutrire Diatita, 7(1), 16-23.
Smith, W. (2006). Contemporary nutrition, 7 edition. USA: McGraw-Hill Companies.

World Health Organization. (2010). Global recommendations on physical activity for health. Geneva: WHO Press. Diakses dari http:// apps.who.int/iris/bitstream/10665/44399/1/978 9241599979_eng.pdf. 